Short Communication

\title{
IMPROVEMENT OF MANAGEMENT OF RHAGOLETIS CERASI IN BOSNIA AND HERZEGOVINA BASED ON A PHENOLOGICAL MODEL
}

\author{
Branimir Nježić ${ }^{1, \#}$, Dušan Pećanin ${ }^{1}$, and Gordana Đurić ${ }^{1,2}$ \\ ${ }^{1}$ Faculty of Agriculture, University of Banja Luka, Bulevar vojvode Petra Bojovića 1A, 78000 Banja Luka, Bosnia and Herzegovina; \\ dusanpecanin@yahoo.com \\ ${ }^{2}$ Genetic Resources Institute, University of Banja Luka, Bulevar vojvode Petra Bojovića 1A, 78000 Banja Luka, Bosnia and Herzegovina; \\ gordana.djuric@griunibl.rs.ba \\ \# Corresponding author branimirnjezic@agrofabl.org
}

Communicated by Biruta Bankina

\begin{abstract}
European cherry fruit fly (Rhagoletis cerasi) is the key pest of sweet and sour cherry throughout Europe. Pest management is usually based on pesticide application. The key of successful management is knowing the proper time of pesticide application, based on the phenological model. To develop a phenological model, a local population of the pest from the northern part of Bosnia and Herzegovina was studied. First adult appearance and population densities were monitored by yellow sticky traps. Soil and air temperatures were compared at two thermal thresholds, $5{ }^{\circ} \mathrm{C}$ and $7^{\circ} \mathrm{C}$. Air temperature was applied in the model since it is more suitable for farmers and is related to soil temperature. Both thermal thresholds can be used. The first adult flies were captured after 435 degree-days (dd) and the first cumulative 5\% of the catch after $605 \mathrm{dd}$. These two times should be considered for time of application of pesticides. Regarding time for first egg hatch, the first larva burrowed into fruits at $730 \mathrm{dd}$. Cultivars that can be harvested beginning on the $730 \mathrm{dd}$ calculate from 1 March are considered to have low risk of cherry fruit fly damage.
\end{abstract}

Key words: European cherry fruit fly, flight dynamics, cherry, yellow sticky traps.

European cherry fruit fly (Rhagoletis cerasi) is the most important pest of sweet cherries (Prunus avium) in Europe. It is a univoltine oligophagous species (Wiesmann, 1933) that attacks also sour cherry (Prunus cerasus) and mahaleb cherry (Prunus mahaleb). It overwinters in a cocoon buried in soil at depth $2-5 \mathrm{~cm}$. Its life cycle is closely adapted to the phenology of host plants. Adults emerge in spring but a portion of the population remains in diapause for 2 or 3 years to prevent population extinction in case of failure of host plants to fruit. After emergence, adults feed on carbohydrates, proteins and water, usually on cherry plants, and maturation to development of gonads is temperature dependent. After mating, females insert a single egg by means of an ovipositor under the skin of young fruit. In order to avoid multiple oviposition within the same fruit and larval competition, during oviposition the female leaves a water soluble pheromone recognised by other females (Katsoyannos, 1975). After embryonic development, freshly hatched larva move to the cherry pit. During the development, the larvae tunnel fruit and feed on fruit tissue. The larvae mature around harvest, and exit through a hole in the fruit skin to pupate in the soil (Daniel and Grunder, 2012).
Without control measures, $100 \%$ of cherry fruits can be infested with $R$. cerasi. An additional challenge for farmers is a low market tolerance of only $2 \%$ of damaged fruits (Daniel and Baker, 2013). Insecticides provide protection with reliable control. Previously, Dimethoata was the standard pesticide for cherry fruit fly control, but it is no longer registered in Switzerland and many other countries (Daniel and Grunder, 2012). The current control strategy in these countries is based on neonicotenoids and pyretroids. In organic production, mechanical and biological control methods are applied. Yellow sticky traps can be used for mass trapping, but several traps are necessary per tree (Boller, 1972). Covering the soil or trees with nets can reduce damage by $91 \%$ (Balmer, 2005), but his method is rather expensive. Foliar application of Naturalis-L based on the entomoptahogenic fungi Bauveria bassiana can reduce the infestation level by 60-70\% (Daniel and Wyss, 2010).

The life cycle of cherry fruit flies is synchronised with the host fruiting pattern, but it follows a temperature driven model (Kovanci and Kovanci, 2006). Yellow sticky traps were developed based on colour preference of adult cherry fruit fly for adult capture (Boller, 1983). They are used to 
determine beginning and length of flight of cherry fruit fly. Soil temperature and degree-days (DD) are used to estimate time of the adult appearance. Two thresholds have been proposed: $5{ }^{\circ} \mathrm{C}$ with $430 \mathrm{DD}$ (Boller, 1964) and $7{ }^{\circ} \mathrm{C}$ with 320 DD (Leski, 1963). However, Boller and Bush (1974) and Kovanci and Konavci (2006) observed that the DD differed between populations.

The major aim of this study was to determine onset of cherry fruit fly flight based on accumulated soil and air temperatures to propose a more precise model of pesticide application.

The study was conducted in northern Bosnia and Herzegovina, locality Turjak $\left(44^{\circ} 59^{\prime} \mathrm{E} ; 17^{\circ} 08^{\prime} \mathrm{N}\right)$ in municipality Gradiška. The orchard consisted of 600 trees planted in 2007 at distance $4 \times 2 \mathrm{~m}$, with cultivars 'Burlat', 'Sylvia', 'Regina' and 'Cordia'. Average yield was 7-10 kg per tree for the early ripening cultivars 'Burlat' and 'Sylvia' and $12-15 \mathrm{~kg}$ for the other two cultivars. Cherry fruit fly management was based on 1-2 larvicide insecticide applications at time of colour change in cultivars 'Regina' and 'Cordia' in 2014, while in 2015 and 2016 no insecticides were applied against this pest. Cherry fruit fly activity was monitored using yellow sticky traps with dimensions $25 \times 40 \mathrm{~cm}$, produced by Kollant s.r.l., Italy. The traps were placed on the external southern part of tree canopies at height $1.5 \mathrm{~m}$ before anticipated day of start of flight activity. Flies per trap were counted at weekly intervals. The traps were arranged regularly throughout the orchard.

Daily temperature was recorded at soil depth $5 \mathrm{~cm}$ and at 2 $\mathrm{m}$ above ground by weather stations. Meteorological data from the station Gradiška of Hidrometorological Service of Republic of Srpska, located $13 \mathrm{~km}$ from the orchard were used. Starting date for calculations was 1 March. Two thermal thresholds were calculated: $5{ }^{\circ} \mathrm{C}$ and $7{ }^{\circ} \mathrm{C}$. Daily average temperature was used for temperature sum calculation.

The level of damage was monitored on cultivar 'Regina'. 100 fruits were collected from five trees and examined in the laboratory. Fruits were examined for emergence holes then, broken and suspended in $10 \%$ salt solution to force larvae emergence. Number of larvae was determined.

Thermal threshold $5^{\circ} \mathbf{C}$. The first fly captures in 2015 and 2016 were on 9 May and 16 May, respectively. The temperature sums that were accumulated from 1 March until the day of first fly capture in 2015 were after 451 dd and 435 dd for soil and air temperature respectively when $5{ }^{\circ} \mathrm{C}$ was chosen as the thermal threshold (Fig. 1). In 2016, the accumulated temperature sums were 543 and 490 dd for soil and air temperature, respectively (Fig. 1). Cumulative 5\% catch was reached after $657 \mathrm{dd}$ and $605 \mathrm{dd}$ in 2015 for soil and air temperature, respectively, and in 2016 after 682 dd and 610 dd. Duration of flight period was between 848 dd and 716 dd in 2015 for soil and air temperature, respectively, and in 2016 between $840 \mathrm{dd}$ and $745 \mathrm{dd}$. The flight lasted 51 and 48 days, respectively, in 2015 and 2016.

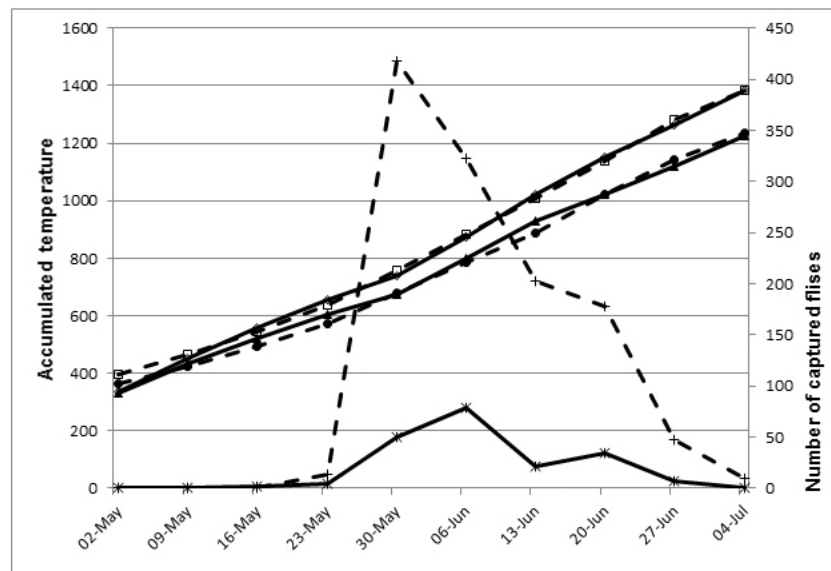

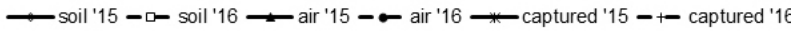

Fig. 1. Accumulated soil and air temperatures from 1 January to reach threshold $5{ }^{\circ} \mathrm{C}$ and weekly catch of $R$. cerasi in 2015 and 2016.

Thermal threshold $7{ }^{\circ} \mathrm{C}$. When $7{ }^{\circ} \mathrm{C}$ was chosen as thermal threshold the temperature sums that were accumulated from 1 March until the day of first fly capture in 2015 were after 334 dd and 319 dd for soil and air temperature, respectively, while in 2016 after 398 dd and 358 dd (Fig. 2). Cumulative 5\% catch was reached in 2015 after 512 dd and $460 \mathrm{dd}$ for soil and air temperate, respectively, while in 2016 after 517 dd and 457 dd. Duration of flight period in 2015 was between 746 dd and 613 dd for soil and air tem-
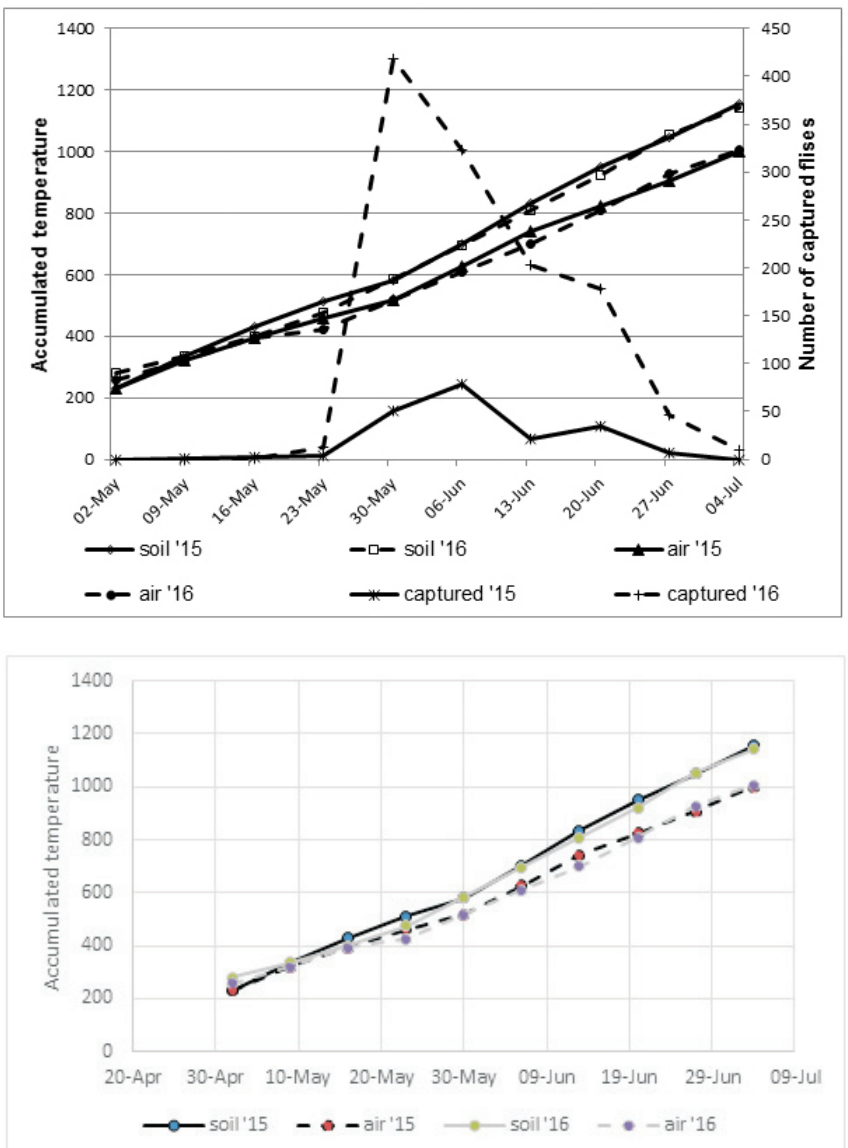

Fig. 2. Accumulated soil and air temperatures from 1 January to reach threshold $7{ }^{\circ} \mathrm{C}$ and weekly catch of $R$. cerasi in 2015 and 2016. 
peratures, respectively, and in 2016 between $744 \mathrm{dd}$ and 649 dd.

Harvest and damage. In 2015, harvest began on 14 May, 18 May, 2 June, and 6 June for cultivars 'Burlat', 'Sylvia', 'Regina', and 'Cordia', respectively. In 2016, harvest of these cultivars began on 7 May, 11 May, 2 June, and 4 June. In 2015, the average damage on cultivar 'Regina' was $79 \%$, while in $2016-90.3 \%$.

\section{DISCUSSION}

There was no difference in accumulated temperature sums of first fly catch when soil and air temperatures were compared for $5{ }^{\circ} \mathrm{C}$ and $7{ }^{\circ} \mathrm{C}$ thermal thresholds in the two studied years. However, some differences were observed between temperature sums calculated from soil and air temperatures for $5 \%$ cumulative hatch and more so for duration of flight period. Different populations of $R$. cerasi pupae exposed to constant chilling temperatures in the range $0-12{ }^{\circ} \mathrm{C}$ for different times overcome diapause in relation to adaptation of the local populations (Moraiti et al., 2014). Our study showed that $5^{\circ} \mathrm{C}$ and $7{ }^{\circ} \mathrm{C}$ can be used as thermal thresholds for accumulation of degree days for the studied population, since no major differences were observed between the two thresholds. There were differences in accumulated temperature for day of first fly catch but the cumulative $5 \%$ catch was more stable.

Different models of first adult emergence were proposed based on accumulated temperature sums for cherry fruit fly (Boller, 1964; Baker and Miller, 1978, Kovanici and Kovanici, 2006) and for the closely related species Rhagoletis indifferens present in the North America (AliNiazee, 1976; 1979; Jones et al., 1991). The thermal threshold in the majority of studies was $5{ }^{\circ} \mathrm{C}$ with 1 March as starting day of accumulation. In our study accumulation from this date was less variable among years than for accumulation from 1 January. Accumulated degree days for thermal threshold varied in different studies from $430 \mathrm{dd}$ (Baker and Miller, 1978) up to $667 \mathrm{dd}$ (Kovanici and Kovanici, 2006), indicating differences among local populations. For each locality the model should be tested for one or more seasons (Kovanici and Kovanici, 2006). Our results for the tested locality suggest that accumulated degree days is $450 \mathrm{dd}$ calculated from 1 March to reach the $5^{\circ} \mathrm{C}$ thermal threshold.

In the model of Rhagoletis indifferens (AliNiazee, 1979) $132 \mathrm{dd}$ are reported as required from first emergence until egg hatch. In cases of lacking data on the thermal requirements for developmental stages of a particular species, data for closely related species can be used for estimates (Jarošik et al., 2011). Adding this period of $132 \mathrm{dd}$ to accumulation for first fly catch, we can estimate the dd required for first fruit infestation in an orchard. In our study, harvest of two cultivars started at time of first fly catch, indicating that they cannot be affected by cherry fruit fly larvae. All cultivars with start of harvest before the time of accumu- lated dd for egg hatch avoid problems concerning cherry fruit fly. Moreover, 5\% cumulative fly catch can be considered as a low risk population size for damage. To reach $5 \%$ cumulative fly catch, an additional $142 \mathrm{dd}$ are required and for first hatch $132 \mathrm{dd}$ are required. An additional $270 \mathrm{dd}$ leaves adequate time for harvest of cultivars, which indicates low risk of damage by $R$. cerasi. We suggest that cultivars for which harvest begins before $730 \mathrm{dd}$ calculated from 1 March are considered to have low risk of cherry fruit fly damage.

Lack of insecticide application resulted in increased number of infested fruits in the orchard for the latest ripening cultivar 'Regina'. A very high level of infestation also occurred in the first year without insecticide application, indicating a high population size in the previous year. This could be due improper pesticide application and incomplete harvesting where some fruits were left in the tree canopy. These fruits present sites that support growth of the fly population, and they should be removed and destroyed.

The observed high level of damage (79\% and 90.3\%) caused by cherry fruit fly in the studied years decreased fruit quality for fresh market, which accepts only up to $2 \%$ damage (Daniel and Baker, 2013). In practice, management of cherry fruit fly can be improved by more efficient application of insecticides based on the fly phenological model. Accumulated 5\% fly catch occurs at 605 dd calculated from 1 March for thermal threshold of $5{ }^{\circ} \mathrm{C}$. Soil and air temperatures are both reliable for the phenological model. Pesticide application should be targeted on adult or egg stage. Complete harvest and/or post harvest pesticide application should be incorporated in management practice to decrease the fly population size in the following year. Low risk cultivars are those for which harvest can start by time of $730 \mathrm{dd}$, and these can be grown without pesticide application for management of cherry fruit fly.

\section{ACKNOWLEDGEMENTS}

This study was supported by the Ministry of Science and Technology of Republic of Srpska, Bosnia and Herzegovina, Project No. 19/6-020/961-137/14.

\section{REFERENCES}

AliNiazee, M. T. (1976). Thermal unit requirements for determining adult emergence of the Western cherry fruit fly (Diptera: Tephritidae) in the Willamette Valley of Oregon. Environ. Ent., 5, 397-402.

AliNiazee, M. T. (1979). A computerized phenology model for predicting biological events of Rhagoletis indifferens (Diptera: Tephritidae). Can. Ent., 111, 1101-1109.

Baker, C. R. B., Miller, G. W. (1978). Effect of temperature on postdiapause development of 4 geographical populations of European Cherry Fruit Fly (Rhagoletis cerasi). Entomol. Exp. Appl., 23, 1-13.

Balmer, M. (2005). Kulturschutznetze zur Kontrolle der Kirschfruchtfliege im überdachten Anbau. Obstbau, 1, 14-16 (in German).

Boller, E. F. (1964). Auftreten der Kirschenfliege (Rhagoletis cerasi) und Prognose mittels Boden-temperaturen im Jahre 1963. Schweizerische Zeitschrift fur Obst-Weinbau, 73, 53-58 (in German). 
Boller, E. (1972). Zum Verkauf und Einsatz neuer Kirschenfliegenfallen im Jahre 1972. Schweiz. Z. Obst-und Weinbau, 108, 84-87.

Boller, E. F., Bush, G. L. (1974). Evidence for genetic variation in populations of the European cherry fruit fly, Rhagoletis cerasi (Diptera: Tephritidae) based on physiological parameters and hybridization experiments. Entomologia Experimental et Applicata, 17, 279-293.

Boller, E. (1983). Biotechnical methods for the management of fruit fly populations. In: Cavalloro, R. (Ed.). Fruit Flies of Economic Importance. Balkema, Rotterdam, The Netherlands, pp. 342-352.

Daniel, C., Wyss, E. (2010). Field applications of Beauveria bassiana to control the European Cherry Fruit Fly Rhagoletis cerasi. J. Appl. Entomol., 134, 675-681.

Daniel, C., Grunder, J. (2012). Integrated management of European cherry fruit fly Rhagoletis cerasi (L.): Situation in Switzerland and Europe. Insects, 3 (4), 956-988.

Daniel, C., Baker, B. (2013). Dispersal of Rhagoletis cerasi in commercial cherry orchards: Efficacy of soil covering nets for cherry fruit fly control. Insects, 4, 168-176.

Received 19 August 2016

Accepted in the final form 22 May 2017
Jarošík, V., Honìk, A., Magarey, R.D. and Skuhrovec J. (2011). Developmental database for phenology models: Related insect and mite species have similar thermal requirements. J. Econ. Entomol., 1870-1876.

Jones, V. P., Alston, D. G., Brunner, J. F., Davis, D. W., Shelton, M. D. (1991). Phenology of the Western cherry fruit fly (Diptera: Tephritidae) in Utah and Washington. Ann. Entomol. Soc. Amer., 84, 488-492.

Katsoyannos, B. I. (1975). Oviposition-deterring, male-arresting, fruitmarking pheromone in Rhagoletis cerasi. Environ. Entomol., 4, 801-807.

Kovanci, O. B., Kovanci, B. (2006). Effect of altitude on seasonal flight activity of Rhagoletis cerasi flies (Diptera: Tephritidae). Bull. Entomol. Res., 96, 345-351.

Leski, R. (1963). Studies on the biology and ecology of the cherry fruit fly, Rhagoletis cerasi L. (Dipt., Trypetidae). Polskie Pismo Entomologiczne, Seria B, 153-240 (in Polish).

Moraiti, C. A., Nakas, C. T., Papadopoulos, N. T. (2014). Diapause termination of Rhagoletis cerasi pupae is regulated by local adaptation and phenotypic plasticity: Escape in time through bet-hedging strategies. $J$. Evol. Biol., 27, 43-54.

Wiesmann, R. (1933). Untersuchungen über die Lebensgeschichte und Bekämpfung der Kirschenfliege Rhagoletis cerasi Linné - I. Mitteilung. Landw. Jahrb. Schweiz.. 47, 711-760 (in German).

\section{RHAGOLETIS CERASI KONTROLES UZLABOŠANA BOSNIJĀ UN HERCEGOVINĀ, BALSTOTIES UZ FENOLOG̦ISKO METODI}

Eiropas ķiršu raibspārnmuša (Rhagoletis cerasi) ir visā Eiropā galvenais saldo un skābo ķiršu kaitēklis. Kaitēkḷa kontrole lielākoties balstīta uz kīmisko biocīdu izmantošanu. Pamatojoties uz fenoloğisko modeli, veiksmīgai kontrolei biocīdu izmantošana jāveic pareizajā laikā. Fenoloğiskā modeḷa pilnveidei pētītas kaitēkḷa lokālās populācijas Bosnijas un Hercegovinas ziemeḷu dậā. Pieaugušo mušu sākotnējā parādīšanās un populācijas blīvums uzraudzīts ar dzeltenajiem līmes slazdiem. Augsnes un gaisa temperatūra salīdzināta divos termālajos sākumpunktos $-5^{\circ} \mathrm{C}$ un $7{ }^{\circ} \mathrm{C}$. Gaisa temperatūru var iekḷaut šajā modelī, jo tā ir vairāk piemērota zemniekiem, kā arī nav atšķirību salīdzinājumā ar augsnes temperatūru. Arī abi termālie sākumpunkti var tikt izmantoti. Pirmās pieaugušās mušas noḳertas, temperatūrai sasniedzot $435 d d$ (degree days), un kumulatīvais 5\% k̦ērums bija pie $605 d d$. Pieņemot lēmumu par ierobežošanu, ir jāṇem vērā šie divi punkti. Jāievēro arī laiks, kad šķiļas pirmās olas un kāpuri iegraužas auglī, tas ir - $730 d d$. Škirnes, kurām raža vācama jau pirms $730 d d$, rēḳinot no 1. marta, mušu kaitējuma ziņā ir uzskatāmas kā zema riska. 